\title{
Nursing care quality: a study carried out in Portuguese hospitals
}

\author{
Qualidade dos cuidados de enfermagem: um estudo em hospitais portugueses \\ Calidad de los cuidados de enfermería: un estudio en hospitales portugueses
}

Olga Ribeiro*; Maria Manuela Ferreira Pereira da Silva Martins**; Daisy Maria Rizatto Tronchin***

\begin{abstract}
Background: In a constant pursuit for professional excellence, nurses are required to comply with the quality standards of nursing care. Thus, it is essential to understand this phenomenon in the hospital setting.

Objectives: To analyze nurses' perception of the implementation of quality standards in nursing care.

Methodology: A quantitative, descriptive-exploratory study was conducted in 36 public hospital institutions located in mainland Portugal, involving a total of 3.451 nurses. Data were collected using a questionnaire.

Results: Most nurses often or always performed activities that enhance the quality of nursing care. This analysis showed that nurses perceive activities related to Health Promotion, Well-being and Self-care, and Functional Readaptation as less implemented. On the other hand, activities related to Responsibility and Rigor and Prevention of Complications are implemented most often.

Conclusion: The findings suggest that nursing practices should be redesigned and adjusted based on the activities that are less often implemented.
\end{abstract}

Keywords: nursing care; quality assurance, health care; nursing; hospitals

\section{Resumo}

Enquadramento: Numa procura permanente da excelência no exercício profissional, é exigido aos enfermeiros uma atuaçáo congruente com os padrôes de qualidade dos cuidados de enfermagem, sendo pertinente perceber o fenómeno no contexto hospitalar.

Objetivos: Analisar a perceção dos enfermeiros relativamente à concretizaçáo dos padrões de qualidade dos cuidados de enfermagem.

Metodologia: Estudo exploratório-descritivo, de carácter quantitativo, realizado em 36 instituiçóes hospitalares EPE de Portugal continental, com a participação de 3,451 enfermeiros. Como instrumento de colheita de dados usámos o questionário.

Resultados: A maioria dos enfermeiros concretiza às vezes ou sempre as atividades que contribuem para a qualidade dos cuidados de enfermagem. Decorrente da análise efetuada, as atividades inerentes às dimensóes Promoçáo da saúde, Bem-estar e autocuidado e Readaptação funcional, são aquelas que os enfermeiros percecionam como menos executadas. Por outro lado, as atividades mais frequentemente concretizadas, reportam-se às dimensôes Responsabilidade e rigor e Prevenção de complicações.

Conclusáo: Os dados sugerem a necessidade de se repensarem as práticas, no sentido de uma atuação congruente com os enunciados descritivos menos frequentemente concretizados.

Palavras-chave: cuidados de enfermagem; garantia da qualidade dos cuidados de saúde; enfermagem; hospitais

*Doctoral student, Nursing Sciences, University of Porto, Abel Salazar Institute of Biomedical Sciences, 4050-313 Porto, Portugal [olgaribeiro25@hotmail.com]. Contribution to the article: literature search, data collection, statistical treatment and evaluation, data analvsis and discussion, article writing.

Address for correspondence: Travessa Antero Quental, no 173/175, 4049-024, Porto, Portugal. ***Ph.D., Coordinating Professor, Nursing School of Porto, 4200-072 Porto, Portugal [mmartins@esenfc.pt]. Contribution to the article: statistical treatment and evaluation, data analysis and discussion.

****Ph.D., Associate Professor, University of Sao Paulo, 05403-000, São Paulo, Brazil [daisyrt@usp.br]. Contribution to the article: data analysis and discussion.

\section{Resumen}

Marco contextual: En una búsqueda permanente de la excelencia en el ejercicio profesional, se exige que los enfermeros actúen de forma congruente con los patrones de calidad de los cuidados de enfermería, para lo cual es pertinente comprender el fenómeno en el contexto hospitalario.

Objetivos: Analizar la percepción de los enfermeros en relación a la concretización de los patrones de calidad de los cuidados de enfermería.

Metodología: Estudio exploratorio y descriptivo, de carácter cuantitativo, realizado en 36 instituciones hospitalarias EPE de Portugal continental, en el que se contó con la participación de 3.451 enfermeros. Como instrumento de recogida de datos se usó el cuestionario.

Resultados: La mayoría de los enfermeros realiza a veces o siempre las actividades que contribuyen a la calidad de los cuidados de enfermería. A partir del análisis efectuado, las actividades inherentes a las dimensiones Promoción de la salud, Bienestar y autocuidado y Readaptación funcional son aquellas que los enfermeros perciben como menos ejecutadas. Por otro lado, las actividades que se realizan con más frecuencia se refieren a las dimensiones Responsabilidad y rigor y Prevención de complicaciones.

Conclusión: Los datos sugieren que es necesario repensar las prácticas con el objetivo de realizar una actuación congruente con los enunciados descriptivos que se ponen en práctica con menos frecuencia.

Palabras clave: atención de enfermería; garantía de la calidad de atención de salud; enfermería; hospitales

Received for publication: 20.12 .16

Accepted for publication: 15.03 .17 


\section{Introduction}

As a result of the complexity of health care, increased life expectancy, and citizens' higher expectations, health care systems worldwide face a growing need to provide safe and quality care. In Portugal, the quality of health care is one of the priorities of the Directorate-General for Health, which is evident in the National Strategy for Health Quality 2015-2020 adopted by Decision No. 5613/2015 of 27 May. According to this document:

Health care quality, which is defined as the provision of accessible and equal care, at an optimal professional level and that takes into account the available resources and leads to citizen adherence and satisfaction, implies the adequacy of care to the citizen's needs and expectations. (p.13551)

In this context, care quality and safety are an ethical obligation, because they significantly contribute to reducing avoidable risks and improving access to care, equity, and respect in care delivery. However, according to Pereira (2009), although the concept of improvement is essential in terms of quality, the philosophy that currently underpins health care quality adds the concept of continuity to the principle of improvement, involving each and every one of those involved in the process. In addition, the author clarifies that it challenges each one to contribute to the continuous improvement of quality as a dynamic and progressive reality, particularly in the health area. In light of the above, it is generally agreed that the development of quality in health is a multidisciplinary task. "Clearly, neither health care quality can be achieved solely through nurses' professional exercise nor nurses' professional exercise can be neglected or left invisible, in the efforts to attain health care quality" (Ordem dos Enfermeiros, 2012 , p. 6). In 2001, as a result of the importance of nurses' contribution to health care quality, the Nursing Council of the Ordem dos Enfermeiros (Portuguese Order of Nurses - national nursing and midwifery regulator) considered the definition of quality standards in nursing care to be a challenge. Since that moment, these standards have been consid- ered as an instrument with the potential to promote continuous quality improvement. However, and although efforts have been made over the last decade to implement quality standards in hospital institutions, as well as to promote nurses' implementation of these standards, some weaknesses are evident. In view of the above, and within the scope of a broader research (Contexts of hospital practice and nursing perceptions: perspectives on the reality of the quality and the ideal of excellence in nurses' professional practice), this study aimed to analyze nurses' perceptions regarding the implementation of quality standards in nursing care in hospital settings.

\section{Background}

The search for quality in nursing has its origin in the early days of the profession. In the $19^{\text {th }}$ century, Florence Nightingale already highlighted the need to gather epidemiological data to identify the quality of care delivery. According to Caldana, Gabriel, Bernardes, and Évora (2011), there has always been, at least informally, a control of the quality of nursing care, which is represented by nurses' concern to carefully follow procedures, believing that, by doing so, they can produce the expected outcomes. In a retrospective analysis of the evolution of nursing, Machado (2013) believes that there is a persevering connection to the concepts of quality and continuous quality improvement. At the international level, hospital institutions that aim to strengthen the contribution of nursing to the improvement of processes and outcomes, have been investing in the development and implementation of professional practice models, which are essential to the promotion of excellence in nursing practice (Stallings-Welden \& Shirey, 2015). In Portugal, the constant search for excellence in professional practice is regulated. The Nursing Council of the Ordem dos Enfermeiros (2001), on the occasion of the definition of the quality standards in nursing care, put forward six categories of descriptive statements: patient satisfaction; health promotion; prevention of complications; well-being and self-care; functional readaptation; and nursing care organization. These de- 
scriptive statements aim to explain the nature and the different aspects of social mandates in nursing; for patients, they represent the assurance of quality nursing care, and for nurses they are a common reference and guide for excellence in professional practice (Ordem dos Enfermeiros, 2012). According to Potra (2015), they form a conceptual matrix with the potential to guide nurses professional practice by promoting and enabling, for example, the reflection about care delivery and the guidance on decision-making in nursing, as well as the visibility of the autonomous dimension of professional practice. Therefore, quality standards indicate to the populations what they can expect in terms of nursing care, and to nurses what is expected from them as a whole and individually for a quality professional practice. Indeed, in a context where issues such as health care quality prevail, excellence in nurses' practice should be promoted, which implies the delivery of nursing care consistent with the professional practice standards.

\section{Research question}

How do nurses of public hospital institutions in mainland Portugal perceive the implementation of quality standards in nursing care?

\section{Methodology}

A descriptive-exploratory study was conducted using a quantitative approach. The focus of attention was the hospital practice in Portugal; hence, a study was designed to be conducted in all hospital institutions with a public enterprise management model (EPE). There were 38 EPE hospitals in Portugal at the time of research development. Given that two hospital institutions refused to participate in the research, the study was conducted in 36 hospital institutions which included hospital centers, hospitals, and local health units, all of them Enterprise Public Entities (EPEs), of the 18 districts in mainland Portugal. The initial plan was to use a probability, random, stratified, and proportional sampling technique; however, it was not possible due to the specificities inherent to the authorization requests to the hospital institutions to carry out the research, namely the impossibility of conducting the study in some clinical settings. Therefore, a nonprobability convenience sampling technique was used (Coutinho, 2014). The following inclusion criteria were defined: being a nurse working in the hospital institution for 6 months or more, in the units of medicine and medical specialties, surgery and surgical specialties or intensive medicine and emergency. Taking into account the units of each hospital institution that authorized the study, the eligible population corresponded to 10.013 nurses. It should be noted that, despite the impossibility of using a probability sampling, the sample included nurses from all hospital institutions who agreed to participate in the study, representing the above-mentioned units. Thus, from an eligible population of 10.013 nurses, with $95 \%$ confidence interval and 5\% significance level, a sample of 3.451 nurses was obtained. Data were collected using the questionnaire Nurses' perceptions and practices: contributions to care quality (Conceçóes e práticas dos enfermeiros: contributos para a qualidade dos cuidados). This questionnaire consisted of two parts: Part I - Participant characterization; Part II - Scale of perception of nursing activities that contribute to nursing care quality (Escala da perceção das atividades de enfermagem que contribuem para a qualidade dos cuidados). This scale was built and validated by Martins, Gonçalves, Ribeiro, and Tronchin (2016). Based on the quality standards, its conceptual structure is divided into 7 dimensions: Patient satisfaction (3 items), Health promotion (3 items), Prevention of complications (3 items), Well-being and selfcare ( 4 items), Functional readaptation ( 4 items), Nursing care organization (2 items), and Responsibility and rigor (6 items). The scale was measured on a 4-point Likert scale, where 1 corresponds to Never, 2 to Rarely, 3 to Often, and 4 to Always. In this study, the Cronbach's alpha coefficient for the total scale was 0.92 , which reveals a very strong internal consistency. It should be noted that the Cronbach's alpha for the original scale was 0.94 (Martins et al., 2016). Data were analyzed using the statistical software Statistical Package 
for the Social Sciences (SPSS), version 22.0. Taking into account the ethical-legal assumptions, in April 2015, we sent a letter to all hospital institutions, EPE, addressed to the board of directors, explaining the study and requesting their participation. Given that all requirements were met, the study was approved by the ethics committees and boards of directors of the 36 hospital institutions involved. Data were collected between July 2015 and January 2016, according to the following procedure: the researcher went to each unit where the study was authorized, the nurse manager was informed about the study, and questionnaires and informed consent forms were delivered. In order to guarantee anonymity, the questionnaires filled out by participants were placed in envelopes. It should be noted that the nurses working in the units were informed in writing about the study objectives, as well as about the procedures involved in the research. This information was made available by the service or the researcher at the unit.

\section{Results}

In relation to the nurses' geographical distribution according to the regional health administration of the hospital institutions where they worked, there was a predominance of the North region $(43.2 \%)$, followed by Lisbon and Tagus Valley (24.0\%), the Center region (22.4\%), Alentejo (6.2\%), and Algarve (4.2\%). In what concerns the distribution of nurses by the units where they work, there was a predominance of the units of medicine and medical specialties (44.2\%), surgery and surgical specialties $(33.7 \%)$, and intensive medicine and emergency (22.1\%). With regard to the participants' sociodemographic and professional profile, most of the 3.451 nurses were women $(77.1 \%)$. The age distribution is asymmetric positive, which means that there is a predominance of the younger ages. Since the minimum age is 22 years, the number of nurses aged up to 25 years is very low and there is a large increase in the number of nurses from 25 up to 35 years. The mean age is 36.4 years, which is above the median of 34 years. Most nurses are married/cohabiting $(61.1 \%)$, followed by those who are sin- gle $(33.9 \%)$, divorced $(4.7 \%)$, and widowed $(0.3 \%)$. With regard to the academic degree, most nurses have a Bachelor's degree (88.0\%), followed by one nurse with a Master's degree $(10.7 \%)$, one with a 3-year degree (Bacharelato) $(1.1 \%)$, and one with a doctoral degree $(0.2 \%)$. In relation to the condition in which they exercise their profession, the majority of professionals are nurses (76.3\%), followed by specialist/specialized nurses $(19.9 \%)$, and nurse managers/head nurses (3.8\%). The distribution of the number of years in the profession among nurses is asymmetric positive, with a predominance of low and intermediate periods of time. In fact, the mean time is 12 years and the median is only 10 years, with a maximum of 39 years and a minimum of 1 year. The distribution of the number of years in the profession among specialist nurses is also positive asymmetric, with a predominance of low and intermediate periods of time. The mean time is 16 years and the median is 14 years, with a maximum of 37 years and a minimum of 1 year. When asked about the number of years in their area of specialization, a high percentage of nurses reported having attended a specialization course, but had no professional practice in the area of specialization (43.3\%), which means that nearly half of these nurses did not work in their area of specialization. The distribution of the number of years in the profession among nurse managers/head nurses is asymmetric negative, with a predominance of intermediate and high periods of time. The mean time is around 27 years and the median is 29 years, with a maximum of 38 years and a minimum of 1 year. With regard to the area of specialization of specialist/specialized nurses, there is a predominance of rehabilitation nursing $(44.6 \%)$, followed by medical-surgical nursing $(37.8 \%)$. In relation to nurse managers/head nurses, there is a predominance of medical-surgical nursing (40.3\%) and rehabilitation nursing $(32.8 \%)$. With regard to training on the quality standards in nursing care, only 1.377 nurses $(39.9 \%)$ reported having had such training.

As a result of the application of the Scale of perception of nursing activities that contribute to nursing care quality (Martins et al., 2016), which was built based on the quality standards set forth by the Ordem dos Enfermeiros 
(2001), within the scope of the patient satisfaction dimension (Table 1), most nurses answered Always (66.36\%), followed by $O f$ ten (33.06\%), Rarely (0.551\%), and Never $(0.029 \%)$ in the activity "Shows respect for the abilities, beliefs, values, and desires of individual patient while providing nursing care". Most nurses answered Always (69.86\%), followed by Often (29.56\%),
Rarely (0.551\%), and Never (0.029\%) in the activity "Constantly seeks to show empathy in interactions with the patient (patient's family)". Finally, most nurses answered Often $(55.3 \%)$, followed by Always (33.4\%), Rarely (11.1\%), and Never (0.2\%) in the activity "Involves significant cohabitants of individual patient in the nursing care process".

Table 1

Distribution of the activities in the Patient Satisfaction dimension

\begin{tabular}{lcccccccccc}
\hline \multirow{2}{*}{ Patient Satisfaction } & \multicolumn{2}{c}{ Never } & \multicolumn{2}{c}{ Rarely } & \multicolumn{2}{c}{ Often } & \multicolumn{2}{c}{ Always } & \multicolumn{2}{c}{ Total } \\
\cline { 2 - 12 } & $n$ & $\%$ & $n$ & $\%$ & $n$ & $\%$ & $n$ & $\%$ & $n$ & $\%$ \\
\hline Patient satisfaction $^{\mathrm{a}}$ & 1 & 0.029 & 19 & 0.551 & 1141 & 33.06 & 2290 & 66.36 & 3451 & 100 \\
Patient satisfaction $^{\mathrm{b}}$ & 1 & 0.029 & 19 & 0.551 & 1020 & 29.56 & 2411 & 69.86 & 3451 & 100 \\
Patient satisfaction $^{\mathrm{c}}$ & 6 & 0.2 & 383 & 11.1 & 1909 & 55.3 & 1153 & 33.4 & 3451 & 100 \\
\hline
\end{tabular}

${ }^{a}$ Shows respect for the abilities, beliefs, values, and desires of individual patient while providing nursing care. ${ }^{\mathrm{b}}$ Constantly seeks to show empathy in interactions with the patient (patient's family). ' Involves significant cohabitants of individual patient in the nursing care process.

With regard to the Health promotion dimension (Table 2), most participants answered Often (66.0\%), followed by Always (27.5\%), Rarely (6.4\%), and Never (0.1\%) in the activity "Identifies the health situation of the population and the resources of patient/family and community". Most participants answered $O f$ ten (53.96\%), followed by Always (29.88\%),
Rarely (15.56\%), and Never (0.6\%) in the activity "Uses the hospitalization time to promote healthy lifestyles". Finally, most participants answered Often (56.7\%), followed by Always (29.7\%), Rarely (13.4\%), and Never $(0.2 \%)$ in the activity "Provides information that generates cognitive learning and new abilities in the patient".

Table 2

Distribution of the activities in the Health Promotion dimension

\begin{tabular}{lcccccccccc}
\hline & \multicolumn{2}{c}{ Never } & \multicolumn{2}{c}{ Rarely } & \multicolumn{2}{c}{ Often } & \multicolumn{2}{c}{ Always } & \multicolumn{2}{c}{ Total } \\
\cline { 2 - 13 } Health Promotion & $n$ & $\%$ & $n$ & $\%$ & $n$ & $\%$ & $n$ & $\%$ & $n$ & $\%$ \\
\hline Health Promotion $^{\mathrm{a}}$ & 5 & 0.1 & 221 & 6.4 & 2276 & 66.0 & 949 & 27.5 & 3451 & 100 \\
Health Promotion $^{\mathrm{b}}$ & 21 & 0.6 & 537 & 15.56 & 1862 & 53.96 & 1031 & 29.88 & 3451 & 100 \\
Health Promotion $^{\mathrm{c}}$ & 7 & 0.2 & 464 & 13.4 & 1956 & 56.7 & 1024 & 29.7 & 3451 & 100 \\
\hline
\end{tabular}

${ }^{a}$ Identifies the health situation of the population and the resources of patient/family and community. ${ }^{b}$ Uses the hospitalization time to promote healthy lifestyles. ${ }^{c}$ Provides information that generates cognitive learning and new abilities in the patient.

With regard to the Prevention of complications dimension (Table 3), most respondents answered Always (57.6\%), followed by Often (41.0\%), Rarely (1.3\%), and Never $(0.1 \%)$ in the activity "Identifies potential problems of the patient". Most participants answered $\mathrm{Al}$ ways $(58.16 \%)$, followed by Often $(39.55 \%)$, Rarely (2.09\%), and Never (0.2\%) in the 
activity "Prescribes and performs interventions to prevent complications". Finally, most participants answered Always $(54.4 \%)$, followed by Often $(42.4 \%)$,
Rarely $(3.0 \%)$, and Never $(0.2 \%)$ in the activity "Evaluates the interventions that help prevent problems or minimize undesirable effects".

Table 3

Distribution of the activities in the Prevention of complications dimension

\begin{tabular}{|c|c|c|c|c|c|c|c|c|c|c|}
\hline \multirow{2}{*}{ Prevention of Complications } & \multicolumn{2}{|c|}{ Never } & \multicolumn{2}{|c|}{ Rarely } & \multicolumn{2}{|c|}{ Often } & \multicolumn{2}{|c|}{ Always } & \multicolumn{2}{|c|}{ Total } \\
\hline & $n$ & $\%$ & $n$ & $\%$ & $n$ & $\%$ & $n$ & $\%$ & $n$ & $\%$ \\
\hline Prevention of complications ${ }^{\text {a }}$ & 3 & 0.1 & 46 & 1.3 & 1414 & 41.0 & 1988 & 57.6 & 3451 & 100 \\
\hline Prevention of complications ${ }^{b}$ & 7 & 0.2 & 72 & 2.09 & 1365 & 39.55 & 2007 & 58.16 & 3451 & 100 \\
\hline Prevention of complications ${ }^{c}$ & 6 & 0.2 & 105 & 3.0 & 1462 & 42.4 & 1878 & 54.4 & 3451 & 100 \\
\hline
\end{tabular}

${ }^{a}$ Identifies potential problems of the patient. ${ }^{b}$ Prescribes and performs interventions to prevent complications.

${ }^{c}$ Evaluates the interventions that help prevent problems or minimize undesirable effects.

With regard to the Wellbeing and self-care dimension (Table 4), most respondents answered Always (51.5\%), followed by Often (46.4\%), Rarely (2.0\%), and Never $(0.1 \%)$ in the activity "Identifies patient's problems that will help improve the patient's well-being and daily activities". Most participants answered Often (52.3\%), followed by Always (44.1\%), Rarely (3.5\%), and Never (0.1\%) in the activity "Prescribes and performs interventions that will help improve the patient's well-being and daily activities". Most respondents answered Often (48.07\%), followed by Always (41.58\%), Rarely $(10.26 \%)$, and Never $(0.09 \%)$ in the activity "Evaluates the interventions that help improve the patient's well-being and daily activities". Finally, most respondents answered Often (46.9\%), followed by Always (42.8\%), Rarely (10.1\%), and Never (0.2\%) in the activity "Addresses problematic situations identified that will help improve the patient's well-being and daily activities".

Table 4

Distribution of the activities in the Well-Being and Self-Care dimension

\begin{tabular}{lcccccccccc}
\hline \multirow{2}{*}{ Well-being and Self-care } & \multicolumn{2}{c}{ Never } & \multicolumn{2}{c}{ Rarely } & \multicolumn{2}{c}{ Often } & \multicolumn{2}{c}{ Always } & \multicolumn{2}{c}{ Total } \\
\cline { 2 - 12 } & $n$ & $\%$ & $n$ & $\%$ & $n$ & $\%$ & $n$ & $\%$ & $n$ & $\%$ \\
\hline Well-being and self-care $^{\mathrm{a}}$ & 4 & 0.1 & 69 & 2.0 & 1600 & 46.4 & 1778 & 51.5 & 3451 & 100 \\
Well-being and self-care $^{\mathrm{b}}$ & 5 & 0.1 & 120 & 3.5 & 1805 & 52.3 & 1521 & 44.1 & 3451 & 100 \\
Well-being and self-care $^{\mathrm{c}}$ & 3 & 0.09 & 354 & 10.26 & 1659 & 48.07 & 1435 & 41.58 & 3451 & 100 \\
Well-being and self-care $^{\mathrm{d}}$ & 8 & 0.2 & 347 & 10.1 & 1618 & 46.9 & 1478 & 42.8 & 3451 & 100 \\
\hline
\end{tabular}

a Identifies patient's problems that will help improve the patient's well-being and daily activities. ${ }^{\mathrm{b}}$ Prescribes and performs interventions that will help improve the patient's well-being and daily activities. ${ }^{c}$ Evaluates the interventions that help improve the patient's well-being and daily activities. ${ }^{\mathrm{d}}$ Addresses problematic situations identified that will help improve the patient's well-being and daily activities.

With regard to the Functional readaptation dimension (Table 5), most participants answered Always (58.9\%), followed by Often (36.5\%), Rarely (4.1\%), and Never (0.5\%) in the activity "Ensures continuity of nursing service provision". Most respondents answered Often (48.3\%), followed by Always
(39.5\%), Rarely (10.9\%), and Never (1.3\%) in the activity "Plans discharge of hospitalized patients in health institutions, according to each patient's needs and community resources". Most respondents answered Often (46.1\%), followed by Always (38.8\%), Rarely (14.2\%), and Never (0.9\%) in the activity 
"Optimizes the abilities of the patient and his/her significant cohabitants to manage the prescribed therapy". Finally, most participants answered Often (47.0\%), followed by Always (38.0\%), Rarely (14.6\%), and Never
$(0.4 \%)$ in the activity "Teaches, instructs, and trains patients for their individual adaptation and teaches, instructs, and trains patients on what is required for their functional readaptation".

Table 5

Distribution of the activities in the Functional readaptation dimension

\begin{tabular}{|c|c|c|c|c|c|c|c|c|c|c|}
\hline \multirow{2}{*}{ Functional Readaptation } & \multicolumn{2}{|c|}{ Never } & \multicolumn{2}{|c|}{ Rarely } & \multicolumn{2}{|c|}{ Often } & \multicolumn{2}{|c|}{ Always } & \multicolumn{2}{|c|}{ Total } \\
\hline & $n$ & $\%$ & $n$ & $\%$ & $n$ & $\%$ & $n$ & $\%$ & $n$ & $\%$ \\
\hline Functional readaptation ${ }^{a}$ & 16 & 0.5 & 143 & 4.1 & 1261 & 36.5 & 2031 & 58.9 & 3451 & 100 \\
\hline Functional readaptation ${ }^{\mathrm{b}}$ & 46 & 1.3 & 375 & 10.9 & 1666 & 48.3 & 1364 & 39.5 & 3451 & 100 \\
\hline Functional readaptation $^{c}$ & 31 & 0.9 & 491 & 14.2 & 1591 & 46.1 & 1338 & 38.8 & 3451 & 100 \\
\hline Functional readaptation ${ }^{d}$ & 15 & 0.4 & 504 & 14.6 & 1622 & 47.0 & 1310 & 38.0 & 3451 & 100 \\
\hline
\end{tabular}

${ }^{a}$ Ensures continuity of nursing service provision. ${ }^{\mathrm{b}}$ Plans discharge of hospitalized patients in health institutions, according to each patient's needs and community resources. ${ }^{c}$ Optimizes the abilities of the patient and his/her significant cohabitants to manage the prescribed therapy. ${ }^{\mathrm{d}}$ Teaches, instructs, and trains patients for their individual adaptation and teaches, instructs, and trains patients on what is required for their functional readaptation.

With regard to the Nursing care organization dimension (Table 6), most participants answered Always (51.14\%), followed by Often (44.4\%), Rarely (4.23\%), and Never $(0.23 \%)$ in the activity "Knows how to handle the nursing record system". Most respondents answered Often (53.2\%), followed by Always (31.85\%), Rarely (14.6\%), and Never $(0.35 \%)$ in the activity "Knows the hospital's policies".

Table 6

Distribution of the activities in the Nursing Care Organization dimension

\begin{tabular}{lcccccccccc}
\hline \multirow{2}{*}{\begin{tabular}{l} 
Nursing Care \\
\cline { 2 - 11 } Organization
\end{tabular}} & \multicolumn{2}{c}{ Never } & \multicolumn{2}{c}{ Rarely } & \multicolumn{2}{c}{ Often } & \multicolumn{2}{c}{ Always } & \multicolumn{2}{c}{ Total } \\
\cline { 2 - 11 }$y$ & $n$ & $\%$ & $n$ & $\%$ & $n$ & $\%$ & $n$ & $\%$ & $n$ & $\%$ \\
\hline Care organization $^{\mathrm{a}}$ & 8 & 0.23 & 146 & 4.23 & 1532 & 44.4 & 1765 & 51.14 & 3451 & 100 \\
Care organization $^{\mathrm{b}}$ & 12 & 0.35 & 504 & 14.6 & 1836 & 53.2 & 1099 & 31.85 & 3451 & 100 \\
\hline
\end{tabular}

${ }^{a}$ Knows how to handle the nursing record system. ${ }^{b}$ Knows the hospital's policies.

In relation to the Responsibility and rigor dimension (Table 7), we found that most respondents answered Always (88.5\%), followed by Often (11.4\%), and Rarely (0.1\%) in the activity "Shows responsibility for the decisions they make and for the acts they perform and delegate, aiming to prevent complications". None of the respondents answered Never. Most respondents answered Always (79.7\%), followed by Often (20.1\%), and
Rarely $(0.2 \%)$ in the activity "Shows responsibility for the decisions they make and for the acts they perform and delegate, aiming to ensure well-being and self-care of patients". None of the respondents answered Never. Most of the participants answered Always (78.2\%), followed by Often (21.5\%), and Rarely $(0.3 \%)$ in the activity "Shows tech$\mathrm{nical} / \mathrm{scientific}$ rigor in the implementation of nursing interventions aiming to prevent 
complications". None of the respondents answered Never. Most participants answered Always (68.3\%), followed by Often $(31.3 \%)$, and Rarely $(0.4 \%)$ in the activity "Shows technical/scientific rigor in the implementation of nursing interventions that help improve the patient's well-being and daily activities". None of the respondents answered Never. Most of the participants answered Always (51.6\%), followed by Often (45.2\%), Rarely (3.1\%), and Never $(0.1 \%)$ in the activity "Refers problematic situations to other professionals, according to the social mandates". Finally, most of the respondents answered $\mathrm{Al}$ ways $(51.9 \%)$, followed by Often $(38.7 \%)$, Rarely (9.3\%), and Never (0.1\%) in the activity "Supervises the activities that support nursing interventions and the activities they delegate".

Table 7

Distribution of the activities in the Responsibility and Rigor dimension

\begin{tabular}{|c|c|c|c|c|c|c|c|c|c|c|}
\hline \multirow{2}{*}{ Responsibility and Rigor } & \multicolumn{2}{|c|}{ Never } & \multicolumn{2}{|c|}{ Rarely } & \multicolumn{2}{|c|}{ Often } & \multicolumn{2}{|c|}{ Always } & \multicolumn{2}{|c|}{ Total } \\
\hline & $n$ & $\%$ & $n$ & $\%$ & $n$ & $\%$ & $n$ & $\%$ & $n$ & $\%$ \\
\hline Responsibility and rigor ${ }^{a}$ & 0 & 0.0 & 4 & 0.1 & 394 & 11.4 & 3053 & 88.5 & 3451 & 100 \\
\hline Responsibility and rigor ${ }^{b}$ & 0 & 0.0 & 8 & 0.2 & 692 & 20.1 & 2751 & 79.7 & 3451 & 100 \\
\hline${\text { Responsibility and } \text { rigor }^{c}}^{c}$ & 0 & 0.0 & 10 & 0.3 & 742 & 21.5 & 2699 & 78.2 & 3451 & 100 \\
\hline Responsibility and rigor ${ }^{d}$ & 0 & 0.0 & 13 & 0.4 & 1080 & 31.3 & 2358 & 68.3 & 3451 & 100 \\
\hline Responsibility and rigor $^{\mathrm{e}}$ & 3 & 0.1 & 107 & 3.1 & 1560 & 45.2 & 1781 & 51.6 & 3451 & 100 \\
\hline Responsibility and rigor ${ }^{f}$ & 5 & 0.1 & 320 & 9.3 & 1336 & 38.7 & 1790 & 51.9 & 3451 & 100 \\
\hline
\end{tabular}

a Shows responsibility for the decisions they make and for the acts they perform and delegate, aiming to prevent complications. ${ }^{b}$ Shows responsibility for the decisions they make and for the acts they perform and delegate, aiming to ensure well-being and self-care of patients. ${ }^{c}$ Shows technical/scientific rigor in the implementation of nursing interventions aiming to prevent complications. ${ }^{\mathrm{d}}$ Shows technical/scientific rigor in the implementation of nursing

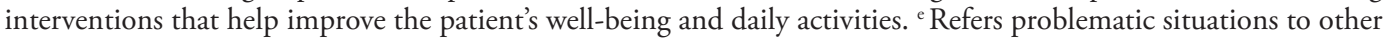
professionals, according to the social mandates. ${ }^{\mathrm{f}}$ Supervises the activities that support nursing interventions and the activities they delegate.

\section{Discussion}

The analysis of the sociodemographic variables showed that the majority of nurses who participated in the study were women (77.1\%) and aged between 25 and 35 years. These results corroborate the data updated by the Ordem dos Enfermeiros in December 2015. The predominance of rehabilitation nursing and medical-surgical nursing as specialization areas is also in line with the data from the regulatory body of the profession. However, it should be noted that $43.3 \%$ of the sampled specialist/specialized nurses do not work in their area of specialization, which shows that nurses' skills are not fully used. In March 2005, within the scope of the quality standards in nursing care, the Ordem dos Enfermeiros launched an intervention project aimed to develop and implement systems for the continuous quality improvement in nurses' professional exercise and for the assurance of care quality, through the nurses' interiorization and use of the quality standards and the involvement of the health care institutions where nurses develop their professional activity. Despite the organization of training sessions throughout the country on quality standards implementation programs, we found that only $39.9 \%$ of the participants in our study had received training on quality standards in nursing care. The application of the Scale of perception of nursing activities that contribute to nursing care quality (Mar- 
tins et al., 2016) has allowed us to objectively identify the activities that provide a key contribution to the quality of nursing care. In relation to the Patient satisfaction dimension, although most of the participants answered Often and Always in the activity "Involves significant cohabitants of individual patient in the nursing care process", $11.1 \%$ of nurses answered Rarely, which expresses the difficulty of integrating significant persons in the process of care delivery. In Ferreira (2015), only $2.4 \%$ of nurse managers felt that the nurses in their teams Rarely performed that activity, which differs from the perception of the nurses in our study. With regard to Health promotion, most participants did not answer Always in any of the activities included in this dimension, which is in line with the results of the study conducted by Ferreira (2015). Although most respondents answered Often in the activities "Uses the hospitalization time to promote healthy lifestyles" and "Provides information that generates cognitive learning and new abilities in the patient", $15.6 \%$ and $13.4 \%$ of nurses answered Rarely, respectively. These results show that, despite the clear evolution of nursing as a discipline and a profession in recent years, nurses professionals still have difficulty in giving priority in clinical practice to an approach focused on the patient and his/her potential (Sousa, Martins, \& Pereira, 2015). According to the International Council of Nurses (2015), nurses are the bedrock of success of patients' behavioral changes throughout the life cycle, by means of approaches focused on health promotion. However, despite the increasing awareness, the results of this study suggest that this domain may not be sufficiently implemented by nurses in hospital settings. Silva, Pinheiro, Souza, and Moreira (2011) consider that the historical and cultural aspects that permeate the hospital as a place of treatment and cure hinder the adoption of health promoting practices. However, and as evidenced by Silva et al. (2011), the World Health Organization's guidelines and the current needs of the population require the development of a new attitude in hospitals, focusing on health rather than disease. This is only possible if practices are redirected towards encouraging patients to reduce risks, prevent diseases, and maxi- mize their potential through a lifestyle-focused approach. In line with what was mentioned above, the National Strategy for Health Quality 2015-2020 challenged health care services to incorporate health promotion and disease prevention initiatives in the same way as they incorporate curative and rehabilitation care with a view to continuously improving care quality (Despacho no 5613/2015 de 27 de maio). Regarding the Prevention of complications dimension, most of the participants answered Always in all activities, which is in line with the study by Ferreira (2015). The results obtained in this dimension indicate the importance of directing nurses' professional practice to the prevention of complications (Pereira, 2009; Machado, 2013). In relation to Well-being and self-care, most nurses Always identified patients' problems, but only Often prescribed, implemented, and evaluated interventions that help improve patients' well-being and daily activities. It should be noted that $10.3 \%$ of nurses answered Rarely in the activity "Evaluates the interventions that help improve the patient's well-being and daily activities". In addition, $10.1 \%$ of nurses answered Rarely in the activity "Addresses problematic situations identified that will help improve the patient's well-being and daily activities". In a study conducted by Ferreira (2015), nurse managers felt that the nurses in their teams Often and Always implemented those activities, which differs from the perception of the nurses in our study. Although the need to assess the results of the implemented interventions is clearly expressed in general and specialist nurses' profiles of competencies, participants recognize that they not Always perform it. With regard to Functional readaptation, most of the nurses answered Always in the activity "Ensures continuity of nursing service provision". Although the majority of the nurses answered Sometimes in the remaining activities, $10.9 \%$ of nurses answered Rarely in the activity "Plans discharge of hospitalized patients in health institutions, according to each patient's needs and community resources". In this dimension, $14.2 \%$ and $14.6 \%$, respectively, of nurses answered Rarely in the activities "Optimizes the abilities of the patient and his/her significant cohabitants to manage the 
prescribed therapy" and "Teaches, instructs, and trains patients for their individual adaptation and teaches, instructs, and trains patients on what is required for their functional readaptation". In the study by Ferreira (2015), nurse managers felt that most of the nurses in their teams Always implemented the activities inherent to the Functional readaptation dimension, which differs from the perception of the nurses in our study. Machado (2013) pointed out that the current nursing paradigm focuses mainly on individuals' skills, potential to face adverse events, and ability to integrate new knowledge and skills with the purpose of allowing patients to be as autonomous as possible, even with some degree of dependence on someone or something. However, the results obtained in this dimension suggest a possible dichotomy between what is reported and what is performed in clinical practice. In relation to the Nursing care organization dimension, although most of the nurses answered Often in the activity "Knows the hospital's policies", we found that $14.6 \%$ of nurses answered Rarely, which corroborates the results obtained by Ferreira (2015). In what concerns the Responsibility and rigor dimension, most of the nurses answered $\mathrm{Al}$ ways in every activity. However, 9.3\% of nurses answered Rarely in the activity "Supervises the activities that support nursing interventions and the activities they delegate". It is well known that nurses, even after delegating the right task, under the right circumstances, to the right person (Parecer $n^{\circ} 136 / 2007$ ), have the duty to supervise, which is not always the case. Despite the contributions of this research, it should be noted that, even though it was an unforeseeable and unavoidable factor, we assume that one of the weaknesses was the fact that a nonprobability sampling technique was used, allowing for the possibility of these results being influenced by the profile of the participating nurses.

\section{Conclusion}

The results obtained with the application of the Scale of perception of nursing activities that contribute to nursing care quality reveal that Portuguese nurses' performance tends to be consistent with the quality standards. Data have also shown that, in general, nurses Often or Always implement the activities inherent to every dimension. As a result of this analysis, it should be noted that the most Often implemented activities relate to the dimensions of Responsibility and rigor and Prevention of complications, which, once again, demonstrates the relevance of action-guiding models focused on the prevention of complications. On the other hand, nurses perceived the activities inherent to the dimensions of Health promotion, Well-being and self-care, and Functional readaptation as less implemented. Therefore, this calls for a reflection on the practice, with a view to achieving a performance that is consistent with the above-mentioned descriptive statements put forward by the Nursing Council of the Ordem dos Enfermeiros. Further qualitative studies should be conducted in order to understand the factors that promote or undermine a performance that is consistent with these statements, with particular attention to those who tend to be less implemented.

\section{References}

Caldana, G., Gabriel, C. S., Bernardes, A., \& Évora, Y. D. (2011). Performance indicators for hospital nursing service: Integrated review. Revista Rene, 12(1), 189-197. Retrieved from http://www.revistarene.ufc.br/revista/index.php/revista/article/ view/146/57

Coutinho, C. P. (2014). Metodologia de investigação em ciências sociais e humanas: Teoria e prática (2a ed.). Coimbra, Portugal: Almedina.

Despacho no 5613/2015 de 27 de maio. Diário da República $n^{o} 102 / 2015,2^{a}$ Série. Ministério da Saúde. Lisboa, Portugal.

Ferreira, C. I. (2015). Gestão em enfermagem e a formação em serviço: Tecnologias de informação e padrōes de qualidade (Master's dissertation). Retrieved from http://hdl.handle.net/10400.26/9756

International Council of Nurses. (2015). Nurses: A force for change: Care effective, cost effective. Geneva, Switzerland: Author.

Machado, N. J. (2013). Gestão da qualidade dos cuidados de enfermagem: Um modelo de melhoria contínua baseado na reflexão-ação (Doctoral thesis). Retrieved from http://hdl.handle.net/10400.14/14957 
Martins, M. M., Gonçalves, M. N., Ribeiro, O. M., \& Tronchin, D. M. (2016). Quality of nursing care: Instrument development and validation. Revista Brasileira de Enfermagem, 69(5), 864-870. doi: 10.1590/0034-7167-2015-0151

Ordem dos Enfermeiros. (2001). Padröes de qualidade dos cuidados de enfermagem: Enquadramento conceptual: Enunciados descritivos. Lisboa, Portugal: Autor.

Ordem dos Enfermeiros. (2007). Parecer no 136/2007 de 23 de abril. Retrieved from http://www.ordemenfermeiros.pt/tomadasposicao/Documents/ EnunciadoPosicao_23Abr2007.pdf.

Ordem dos Enfermeiros. (2012). Padröes de qualidade dos cuidados de enfermagem: Enquadramento conceptual: Enunciados descritivos. Lisboa, Portugal: Autor.

Ordem dos Enfermeiros. (2015). Anuário estatístico. Lisboa, Portugal: Autor.

Pereira, F. (2009). Informação e qualidade do exercício profissional dos enfermeiros. Coimbra, Portugal: Formasau - Formação e Saúde.
Potra, T. M. (2015). Gestão de cuidados de enfermagem: Das práticas dos enfermeiros chefes à qualidade de cuidados de enfermagem (Doctoral thesis). Retrieved from http://hdl.handle.net/10451/20608 Silva, M. A., Pinheiro, A. K., Souza, Â. M., \& Moreira, A. C. (2011). Health promotion in hospital settings. Revista Brasileira de Enfermagem, 64(3), 596-599. doi: 10.1590/S003471672011000300027

Sousa, M. R., Martins, T., \& Pereira, F. (2015). Reflecting on the practices of nurses in approaching the person with a chronic illness. Revista de Enfermagem Referência, 4(6), 55-63. doi: 10.12707/ RIV14069

Stallings-Welden, L. M., \& Shirey, M. R. (2015). Predictability of a professional practice model to affect nurse and patient outcomes. Nursing Administration Quarterly, 39(3), 199-210. doi: 10.1097/NAQ.0000000000000106 
